\title{
Contrasts in genetic structure and historical demography of marine and riverine populations of Atherina at similar geographical scales
}

\author{
Sara M. Francisco ${ }^{\mathrm{a}, \mathrm{b}, *},{\text { Henrique } \text { Cabral }^{\mathrm{c}} \text {, Maria Natividade Vieira }}^{\mathrm{b}}$, Vítor C. Almada ${ }^{\mathrm{a}}$ \\ ${ }^{\text {a }}$ UIE, Instituto Superior de Psicologia Aplicada, Rua Jardim do Tabaco 34, 1149-041 Lisboa, Portugal \\ ${ }^{\mathrm{b}}$ Departamento de Zoologia e Antropologia, Faculdade de Ciências da Universidade do Porto, Praça Gomes Teixeira, 4099-002 Porto, Portugal \\ ${ }^{c}$ Departamento de Biologia Animal \& Instituto de Oceanografia, Faculdade de Ciências da Universidade de Lisboa, R. Ernesto Vasconcelos, \\ 1749-016 Lisboa, Portugal
}

Received 7 March 2006; accepted 8 May 2006

Available online 27 June 2006

\begin{abstract}
In this paper, we compare the genetic structure and the historical demography of two populations of the sand smelt Atherina boyeri from the rivers Tagus and Mondego (Portugal) with two groups of samples of the closely related marine Atherina presbyter collected on the shore at comparable latitudes. A. presbyter is a pelagic marine inshore fish, while A. boyeri is typically found in coastal lagoons, estuaries and freshwaters bodies. Analysis of mtDNA control region sequences showed that the marine A. presbyter did not display signs of genetic differentiation between sites some hundreds of kilometers apart. On the contrary, A. boyeri showed clear differences between populations. The populations of $A$. boyeri showed a much lower genetic diversity and younger coalescence times when compared with A. presbyter. We suggest that these differences reflect the interplay between differences in ecology between the two species and the historical impact of the glaciations. While A. presbyter likely moved to the south evading the cold periods, A. boyeri probably went extinct and its populations in Western Europe are recent recolonizations from western Mediterranean refugia.
\end{abstract}

(C) 2006 Elsevier Ltd. All rights reserved.

Keywords: Atherina presbyter; Atherina boyeri; sand smelt; control region; Portugal; population structure

\section{Introduction}

Fish species that are closely tied to brackish water ecosystems, at least during a part of their life cycle, may present a genetic structure that is the result of two opposing factors: (1) the tendency for differentiation among populations due to geographic isolation, and (2) the homogenizing effects of gene flow among populations which is a function of each species dispersal capability (Ward et al., 1994).

Silversides or sand-smelts (family Atherinidae and related families) are a group of euryhaline marine fish that are also very common in estuaries and, in several parts of the world (e.g. Brazil and Mexico), radiated into substantial species

\footnotetext{
* Corresponding author. Unidade Investigação em Eco-Etologia, Instituto Superior Psicologia Aplicada, Rua Jardim do Tabaco 34, 1149-041 Lisboa, Portugal.

E-mail address: sara_francisco@ispa.pt (S.M. Francisco).
}

flocks in freshwater (e.g. Barbour, 1973; Beheregaray and Sunnucks, 2001; Beheregaray et al., 2002). Bamber and Henderson (1988) and Beheregaray and Sunnucks (2001) hypothesized that the ability of these fish to live in estuaries and lagoons may have played an important role in their repeated radiations and invasions of freshwaters.

In the European Atlantic coast the family Atherinidae is represented by two species of the genus Atherina. Atherina boyeri (Risso, 1810) is a euryhaline teleost fish which inhabits coastal, estuarine and inland waters, forming local semi-isolated populations. Its distribution ranges from the Western Atlantic coast of Spain to Mauritania and Madeira, being found throughout the Mediterranean and Black Sea. Some isolated populations have been reported on the coast of England and the Netherlands (Quignard and Pras, 1986). Several DNA and protein studies have detected a high degree of differentiation (e.g. Congiu et al., 2002; Astolfi et al., 2005), but these studies have focused mainly on Mediterranean populations, and there is a lack of 
knowledge about northeastern Atlantic populations. Atherina presbyter (Cuvier, 1829) is mainly an inshore marine fish that only occasionally enters estuaries and coastal lagoons. Its geographical distribution ranges from the British Isles and southern North Sea to the Canary Islands, Mauritania and Cape Verde, and it has also been reported from the Western Mediterranean Sea (Quignard and Pras, 1986). No DNA studies concerning A. presbyter populations have been reported so far in the literature.

The two species are similar in adult size and size at first maturity (Bamber et al., 1985; Leonardos and Sinis, 2000). Both species spawn demersal eggs that are attached to vegetation in very shallow waters. From these, relatively large larvae, ready to start exogenous feeding, hatch $6.3 \mathrm{~mm}$ TL for Atherina boyeri (Russel, 1976) and 6.7-7.5 mm TL for Atherina presbyter (Bamber et al., 1985). This means that the larval stage, the one that is more prone to passive dispersal, is likely very short, although the adults themselves are active swimmers in the water column. They both present small size, often related to short-range dispersal (Munday and Jones, 1998). One major difference in the ecology of the two species concerns the habitats where they breed and live. A. boyeri may complete its entire life-cycle in brackish or freshwaters (Leonardos, 2001), and surveys in Mediterranean lagoons have revealed that planktonic larval stages develop within their natal lagoons, avoiding dispersal by coastal marine currents (Congiu et al., 2002). It can, however, tolerate high salinities. The marine A. presbyter completes its entire life-history in the sea.

The fact that the breeding biology of the two species is very similar, except for the habitats where reproduction and growth take place, makes this species pair an interesting model to contrast the way different environments affect their population structures. Specifically, it is hypothesized that, for sites separated by comparable distances, the marine Atherina presbyter will present lower genetic differentiation, higher levels of connectivity and larger effective population sizes, when compared to Atherina boyeri. On the other hand, in the case of A. boyeri, the habitat discontinuities between rivers and the small area of the riverine habitat when compared to the coastal one, will favor reduced migration between populations and hence a higher level of population differentiation, together with reduced effective population sizes.

A possible limitation associated with the use of these two species to access the role of varying habitat fragmentation on shaping population structure is the likelihood that the two species were differentially affected by the Pleistocene glaciations. It is widely recognized that the glacial cycles strongly affected the distributions of temperate organisms (Hewitt, 2001). Warm temperate marine fish were no exception (e.g. Domingues et al., 2005). Faced with a drop in water temperature capable of compromising their survival and reproduction, the two Atherina species may have been affected differently. While the marine Atherina presbyter may have simply moved south following the movement of suitable water masses, the riverine populations of Atherina boyeri may have become extinct, recolonizing the Portuguese rivers only when conditions became favorable again after the end of the last glaciation. This possibility of differential effects of the glacial cycles on the populations of the two species means that, when using these fish to compare the effects of environmental differences on population structure, historical factors must also be taken into account.

In this paper, we use sequences of the mitochondrial DNA control region to test three predictions that stem from the hypothesis presented above on the impact of environmental differences on population structure of the two Atherina species: (1) adjacent populations of the marine Atherina presbyter will present less genetic differentiation than riverine populations of Atherina boyeri separated by the same geographical distance; (2) the effective sizes of A. presbyter populations are expected to be greater than those of A. boyeri; and (3) the genetic diversity of $A$. presbyter populations is predicted to be higher than that of populations of $A$. boyeri from similar latitudes. In doing so, the possible differences in the demographic history of the two fish are also considered.

\section{Materials and methods}

Between June 2001 and May 2003, 50 specimens of Atherina presbyter were collected from two sites along the Portuguese west coast: Aveiro $\left(40^{\circ} 38^{\prime} \mathrm{N}, 08^{\circ} 45^{\prime} \mathrm{W}\right)(n=24)$ and Fonte-da-Telha $\left(38^{\circ} 32^{\prime} \mathrm{N}, 09^{\circ} 13^{\prime} \mathrm{W}\right)(n=26)$. The same total number of individuals of Atherina boyeri were collected from two Portuguese river basins, in flowing freshwater, between June and July 2003: Mondego $\left(40^{\circ} 07^{\prime} \mathrm{N}, 38^{\circ} 38^{\prime} \mathrm{W}\right)(n=28)$ and Tagus $\left(39^{\circ} 06^{\prime} \mathrm{N}, 08^{\circ} 32^{\prime} \mathrm{W}\right)(n=22)$ (Fig. 1$)$.

Total genomic DNA extraction was performed on fin samples preserved in $96 \%$ ethanol using the protocol of Sambrook et al. (1989) with some modifications. A fragment from the mtDNA control region was amplified using the primers described in Ostellari et al. (1996): L-pro1 (5'-ACTCT CACCC CTAGC TCCCA AAG-3') and H-DL1 (5'-CCTGA AGTAG GAACC AGATG CCAG-3'). The extraction product was sent to Macrogen (Seoul, Korea) for polymerase chain reaction (PCR) and sequencing. The conditions for these control region amplifications were as follows: amplification in a $20 \mu \mathrm{l}$ volume containing approximately $20 \mathrm{ng}$ of genomic DNA extract, $0.3 \mu \mathrm{l} \mathrm{Taq}$ DNA polymerase (Sogent F-taq), $2 \mu \mathrm{l}$ (10 pmol) of each primer, $3 \mu \mathrm{l}$ of buffer (supplied by the manufacturer) and $1 \mu \mathrm{l}(2.5 \mathrm{mM})$ of each dNTP. PCR was performed using the following profile: an initial denaturing step of $3^{\prime}$ at $95^{\circ} \mathrm{C}$; 35 cycles of denaturing at $95{ }^{\circ} \mathrm{C}$ for $1 \mathrm{~min}$, annealing at $58{ }^{\circ} \mathrm{C}$ for $1 \mathrm{~min}$, and extending at $72{ }^{\circ} \mathrm{C}$ for $1 \mathrm{~min} 30 \mathrm{~s}$; a final extending step of $10 \mathrm{~min}$ at $72{ }^{\circ} \mathrm{C}$. All sequences were aligned using Clustal X (Thompson et al., 1997) with default settings.

For both species, relationships among haplotypes were analyzed with a parsimony network estimated with TCS version 1.21 (Clement et al., 2000), which implements the algorithm of Templeton et al. (1992). Paup* 4.0b (Swofford, 2000) was used to estimate the uncorrected $p$-distances between all sequences.

The Arlequin software package version 3.000 (Excoffier et al., 2005) was used to compute several indices of genetic diversity for each population. The same program was used to access the degree of genetic differentiation between conspecific 


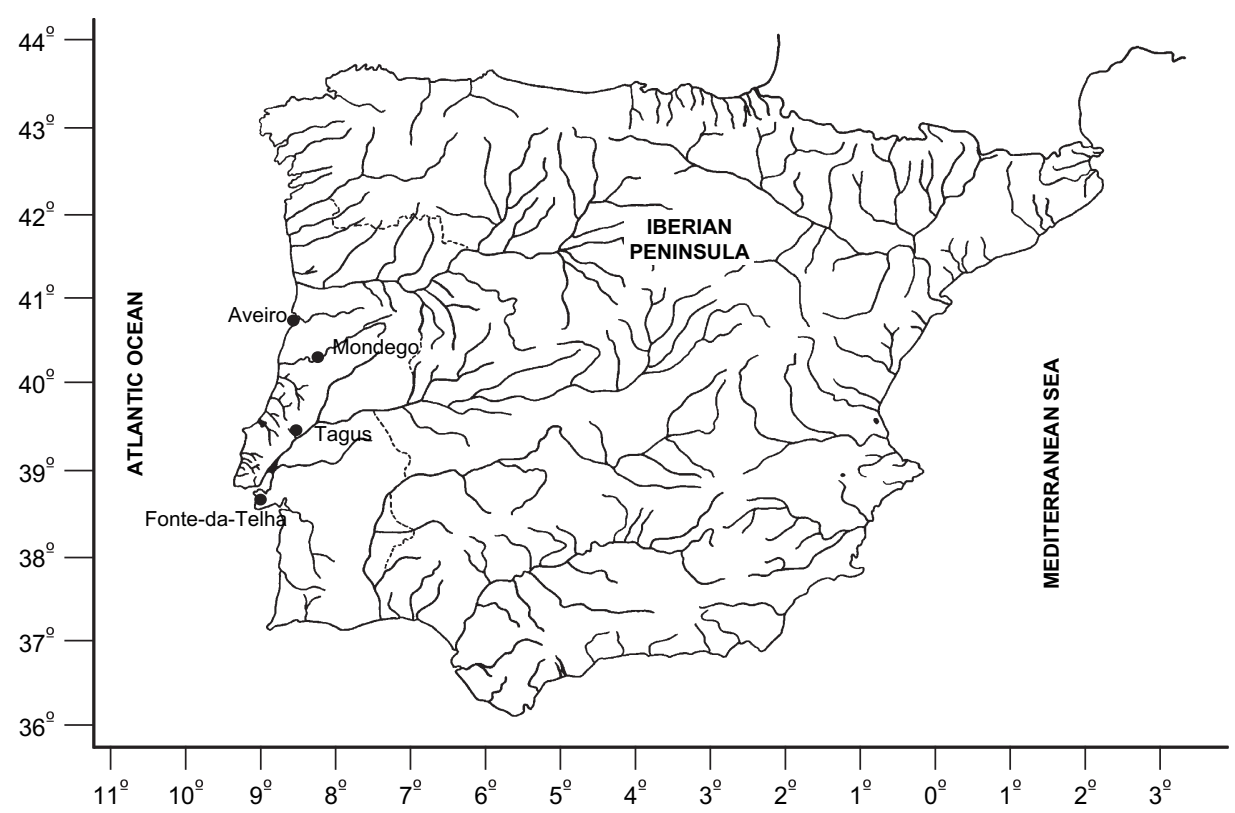

Fig. 1. Sampling locations for Atherina presbyter and A. boyeri along the Portuguese coast and in Portuguese rivers.

populations, performing a one-factor analysis of molecular variance (AMOVA; Excoffier et al., 1992) and an exact test for population differentiation (Raymond and Rousset, 1995).

The possible signature of a glacial reduction in population size during the Pleistocene followed by recent expansion was tested by two approaches. (1) The distribution of mismatches as implemented by Schneider and Excoffier (1999) was analyzed with Arlequin. As mismatch distributions have been found to be very conservative (Ramos-Onsins and Rozas, 2002), we also used the Fu's $F_{\text {s }}$ neutrality test (Fu, 1997). (2) The program Lamarc (Kuhner et al., 2005) was used to estimate the effective population size for each population and its immigration rate $(M)$. These parameters were estimated using two different models: assuming a constant population size versus one that assumes that populations changed in size historically. In this last case, the exponential growth parameter $(g)$ was also estimated by the program. All parameters were estimated with 10 replicate runs using 10 short chains of 500 steps each and 2 long chains of 10,000 , with a sampling increment of 20 .

\section{Results}

The 100 sequences obtained have been deposited in GenBank (accession numbers DQ336715-DQ336814, see Appendix A).

For Atherina presbyter, a total of $382 \mathrm{bp}$ were amplified, while for Atherina boyeri we obtained a fragment of $372 \mathrm{bp}$. For A. presbyter a total of 36 haplotypes (out of 50 individuals) were found, while for $A$. boyeri the total of 50 individuals corresponded only to 13 haplotypes. The various genetic diversity indices are summarized in Table 1. Inspection of this table clearly supports one of the basic predictions of this paper. All the indicators of genetic diversity show that the populations of A. presbyter present higher values than the populations of A. boyeri.

For Atherina presbyter all the haplotypes were linked in the Statistical Parsimony Network under the confidence limit of 95\% (Templeton et al., 1992) (Fig. 2a). The haplotype inferred to be the ancestral one was haplotype 14 (outgroup weight 0.1176) (Castelloe and Templeton, 1994) which comprised 6 specimens from Aveiro and 1 from Fonte-da-Telha. For Atherina boyeri, the corresponding network (Fig. 2b) is dominated by a ubiquitous ancestral haplotype (outgroup weight 0.370 ) shared by 24 individuals (12 from Mondego and 12 from Tagus).

For Atherina presbyter the average uncorrected $p$-distances were $0.0197(\mathrm{SE}=0.0146)$ and $0.0205(\mathrm{SE}=0.0101)$ within Aveiro and Fonte-da-Telha groups of samples, respectively, and 0.0207 ( $\mathrm{SE}=0.0119)$ between them. Atherina boyeri showed an average uncorrected $p$-distance of $0.0025(\mathrm{SE}=0.0019)$ and $0.0030(\mathrm{SE}=0.0027)$ within Mondego and Tagus populations, respectively, and $0.0031(\mathrm{SE}=0.0026)$ between them. The

Table 1

Diversity measures for the populations of Atherina presbyter and A. boyeri. $n$, number of individuals; $n h$, number of haplotypes; $S$, number of polymorphic sites; $H$, gene diversity; $\pi$, nucleotide diversity; $\mathrm{MS}_{\mathrm{aver}}$, average number of mutational steps separating any two haplotypes; $\mathrm{MS}_{\max }$, maximum number of mutational steps separating any two haplotypes

\begin{tabular}{lccccccc}
\hline $\begin{array}{l}\text { Species } \\
\text { population }\end{array}$ & \multicolumn{3}{l}{ Atherina presbyter } & & \multicolumn{3}{l}{ Atherina boyeri } \\
\cline { 2 - 3 } & Aveiro & $\begin{array}{l}\text { Fonte-da- } \\
\text { Telha }\end{array}$ & Total & & Mondego & Tagus & Total \\
\hline$n$ & 24 & 26 & 50 & 28 & 22 & 50 \\
$n h$ & 19 & 22 & 36 & 8 & 9 & 13 \\
$S$ & 35 & 29 & 42 & & 8 & 11 \\
$H$ & 0.946 & 0.978 & 0.968 & & 0.706 & 0.706 & 0.726 \\
$\pi$ & 0.020 & 0.021 & 0.020 & & 0.003 & 0.003 & 0.003 \\
MS $_{\text {aver }}$ & 7.525 & 7.818 & 7.799 & & 0.923 & 1.113 & 1.071 \\
MS $_{\text {max }}$ & 25 & 18 & 25 & 3 & 4 & 5 \\
\hline
\end{tabular}


a

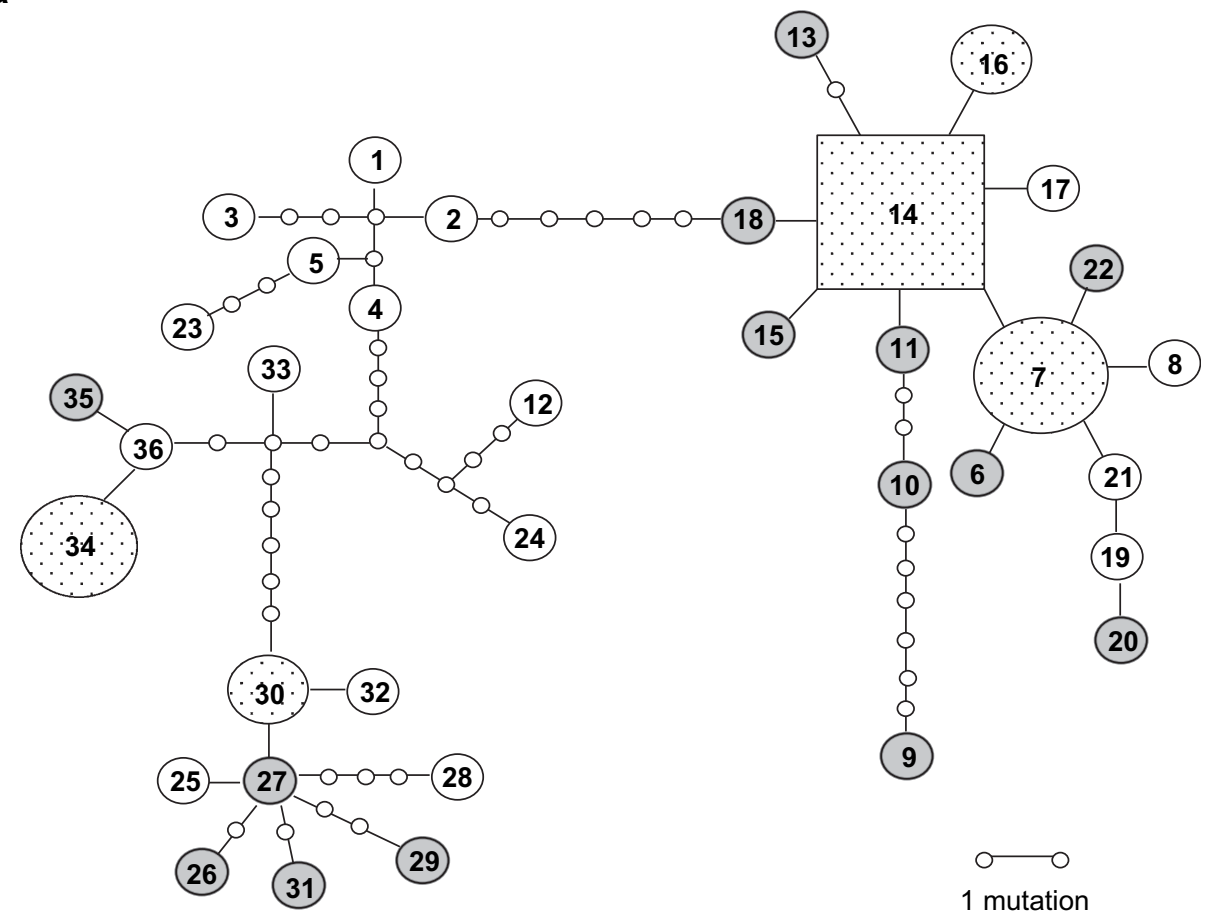

b

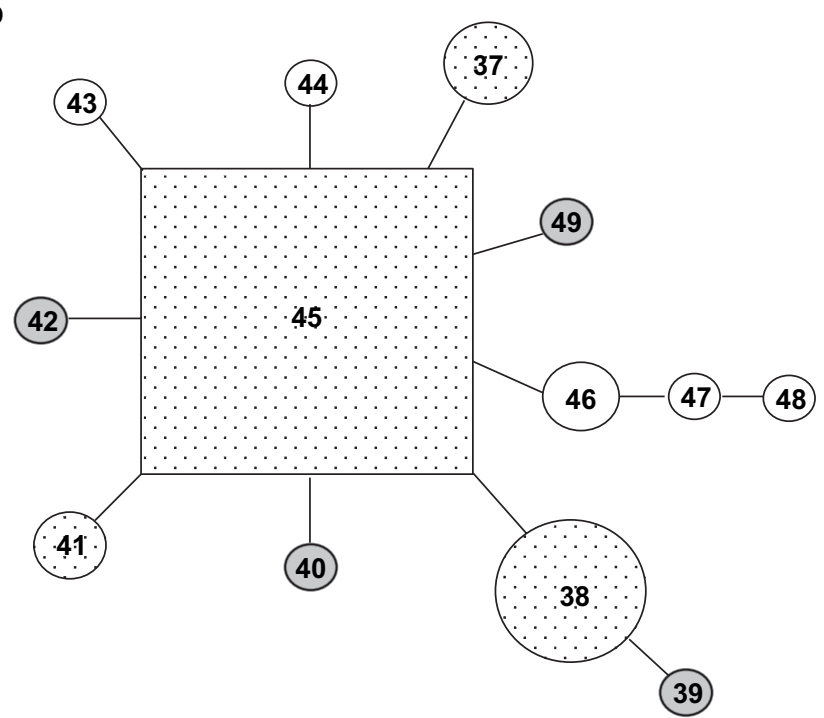

Fig. 2. (a) Statistical parsimony network for 36 control region mtDNA haplotypes of Atherina presbyter in the Portuguese coast. Each haplotype is defined by its corresponding number (see Appendix A). The haplotype with the highest outgroup probability is displayed as a square, other haplotypes as circles. The size of the squares or circles is proportional to the haplotype frequency. White symbols are the Fonte-da-Telha haplotypes, grey symbols are the Aveiro haplotypes and dotted symbols share Fonte-da-Telha and Aveiro haplotypes. (b) Statistical parsimony network for 13 control region mtDNA haplotypes of Atherina boyeri in the two studied Portuguese rivers. Each haplotype is defined by its corresponding number (see Appendix A). The haplotype with the highest outgroup probability is displayed as a square, other haplotypes as circles. The size of the squares or circles is proportional to the haplotype frequency. White symbols are the Tagus haplotypes, grey symbols are the Mondego haplotypes and dotted symbols share Tagus and Mondego haplotypes.

contrast of the values of within population's average uncorrected $p$-distances between the two species expresses the same pattern already shown in Table 1: the populations of $A$. boyeri show a much lower level of genetic diversity than those of $A$. presbyter.

AMOVA revealed that only $3.24 \%$ of the overall variance was due to differences between the two populations of Atherina presbyter and the result was not significant (fixation index
$\left.F_{\mathrm{ST}}=0.0324, P=0.0880\right)$. The exact test of population differentiation was also non-significant $(P=0.2537)$. Given these results, in the subsequent analyses the $A$. presbyter samples were pooled together and treated as a single population. For Atherina boyeri, the AMOVA results revealed that $11.37 \%$ of the overall variance was due to differences between the two populations. The fixation index $F_{\mathrm{ST}}$ was $0.1138(P=0.0029)$, suggesting 
the existence of a genetic structure in the studied area. The exact test of population differentiation was also significant $(P=0.016)$.

There are very large discrepancies in estimations of divergence rates for the control region of teleosts. These estimates are, however, necessary to compute estimates of effective population size and their changes with time from molecular data. In the absence of a specific calibration for the control region of atherinids, we assumed two very distinct rates: $3.6 \%$ and $18.6 \%$ divergence per million years, as these rates have been reported for the mtDNA control region in telelosts (Donaldson and Wilson (1999) and Domingues et al. (2005), respectively). Despite showing a bimodal distribution (not shown), the pairwise mismatch distributions of Atherina presbyter were not significantly different from the sudden expansion model for the whole studied area $(\mathrm{SSD}=0.005, P=0.827)$. This outcome was supported by Fu's $F_{\mathrm{s}}=-18.964(P<0.001)$. Negative and significant values in this test are indicative of population expansion (Fu, 1997). For the A. presbyter population, expansion was estimated to have taken place approximately between 78,000 years ago (ya) (95\% CI 35,459-113,712 ya) and 402,000 ya (95\% CI 183,210-587,515 ya), depending on the mutation rate assumed and considering that the sand smelt is reported to attain full maturity in 1 year (Lorenzo and Pajuelo, 1999). For both Atherina boyeri populations, the least square procedure to fit mismatch distribution and observed distribution did not converge after 1800 steps. The failure to fit a sudden expansion model does not mean, however, that the populations of $A$. boyeri have not experienced a recent historical expansion. Indeed, Fu's neutrality test yielded negative and significant values for both populations: $F_{\mathrm{S}}=-4.486(P=0.001)$ for Mondego and $F_{\mathrm{S}}=-5.777$ $(P<0.001)$ for Tagus,

The estimations of female effective population size and growth parameters for both species, and migration parameters in the case of the populations of Atherina boyeri are presented in Table 2. Inspection of this table shows unambiguously that the effective population size of Atherina presbyter is greater than the sum of the sizes of the two populations of $A$. boyeri. This is true for both the models assuming growth or stability. Regardless of the mutation rate used, the ratio between the effective population size at the Last Glacial Maximum (LGM, 18,000 ya) and its current value for $A$. presbyter was much larger than those of $A$. boyeri. This is indicative of a greater stability in the demographic history of the $A$. presbyter population when compared to those of $A$. boyeri. Population growth rates were also very distinct, with $A$. boyeri's $g$ (exponential growth parameter) being about 12 times higher. The populations of the two species show signs of Pleistocene origin, even with the more conservative mutation rate. Finally, the populations of $A$. boyeri are very young, compared to that of $A$. presbyter.

\section{Discussion}

The present results support the three predictions presented above. Atherina presbyter presents a pattern of high level of gene flow and low degree of differentiation, whereas Atherina
Table 2

Demographic parameters of Atherina presbyter and A. boyeri based on Dloop. Estimates of $M$ (immigration rate), $\theta$ (theta), $N_{\mathrm{f}}$ (female effective population size), $g$ (growth rate), $N_{1 \%}$ (age of population, accessed as the age at which $N_{\mathrm{f}}$ drops below $1 \%$ ) and $N_{18 \mathrm{Kya}} / N_{\text {now }}$ (ratio between $N_{\mathrm{f}}$ at the LGM and currently)

\begin{tabular}{|c|c|c|c|}
\hline \multirow{2}{*}{$\begin{array}{l}\text { Species } \\
\text { population }\end{array}$} & \multirow{2}{*}{$\begin{array}{l}\text { Atherina } \\
\text { presbyter }\end{array}$} & \multicolumn{2}{|l|}{ Atherina boyeri } \\
\hline & & Mondego & Tagus \\
\hline$M$ & - & $\begin{array}{l}364.156 \\
(376.673)\end{array}$ & $\begin{array}{l}503.878 \\
\text { (SE 259.528) }\end{array}$ \\
\hline$\theta$ (no growth) & $\begin{array}{l}0.073 \\
(\text { SE } 0.002)\end{array}$ & $\begin{array}{l}0.005 \\
\text { (SE 0.002) }\end{array}$ & $\begin{array}{l}0.009 \\
\text { (SE 0.003) }\end{array}$ \\
\hline $\begin{array}{l}N_{\mathrm{f}}(\text { no growth }) \\
\quad(\mu=3.6 \% \text { div })\end{array}$ & 2016355 & 127772 & 240230 \\
\hline$(\mu=18.6 \% \operatorname{div})$ & 390262 & 24730 & 46496 \\
\hline$\theta$ (growth) & $\begin{array}{l}0.175 \\
(\mathrm{SE} 0.011)\end{array}$ & $\begin{array}{l}0.105 \\
(\text { SE } 0.219)\end{array}$ & $\begin{array}{l}0.046 \\
\text { (SE 0.026) }\end{array}$ \\
\hline$g$ & $\begin{array}{l}262.944 \\
\text { (SE } 15.566)\end{array}$ & $\begin{array}{l}4098.256 \\
\text { (SE 2674.478) }\end{array}$ & $\begin{array}{l}2538.403 \\
\text { (SE 1025.844) }\end{array}$ \\
\hline $\begin{array}{l}N_{\mathrm{f}} \text { (growth) } \\
\quad(\mu=3.6 \% \mathrm{div})\end{array}$ & 4852330 & 2906805 & 1284230 \\
\hline$(\mu=18.6 \%$ div $)$ & 939161 & 562607 & 248561 \\
\hline $\begin{array}{c}N_{1 \%}(\mu=3.6 \% \text { div })(\mathrm{Kya}) \\
(\mu=18.6 \% \text { div })(\mathrm{Kva})\end{array}$ & $\begin{array}{l}972 \\
188\end{array}$ & $\begin{array}{l}62 \\
12\end{array}$ & $\begin{array}{l}101 \\
19\end{array}$ \\
\hline $\begin{array}{l}N_{18 \mathrm{Kya}} / N_{\text {now }} \\
\quad(\mu=3.6 \% \operatorname{div})(\%)\end{array}$ & 91.83 & 26.51 & 43.93 \\
\hline$(\mu=18.6 \% \operatorname{div})(\%)$ & 64.39 & 0.10 & 1.43 \\
\hline
\end{tabular}

boyeri shows differentiation between the two populations. There are also large differences at the demographic level, with the effective size of the A. presbyter population being greater than those of $A$. boyeri. Finally, the population of $A$. presbyter is also more diverse genetically than the populations of $A$. boyeri. The distances and latitudinal differences between collecting sites were roughly comparable for both species. Their reproductive biology in terms of adult size, egg size and larval duration, is very similar. Thus, the differences found must reflect the differences between the environments where their life-cycles take place, i.e. the sea for $A$. presbyter and the riverine and estuarine habitats for A. boyeri.

Population structure in Atherina boyeri may be generated by homing of the adults to specific spawning grounds and be enhanced by larval retention in a particular river system. Both phenomena will restrict gene flow between populations promoting their divergence with time. In addition, rivers and estuaries provide much reduced areas of available habitat when compared to the sea, thus favoring smaller populations' sizes. Small population size will add to habitat fragmentation increasing random drift of alleles, further enhancing the historical divergence between populations. Astolfi et al. (2005) studding a large number of lagoon populations of $A$. boyeri from Black Sea to Portugal, using a very similar control region fragment, also found an appreciable variation among them. In contrast with Atherina boyeri, A. presbyter did not show signs of differentiation between the studied sites which is consistent with the ability of this fish to disperse easily along the shore.

Our data suggest, however, that in the case of the two Atherina species, the consequences of contrasting ecological settings in the structure of populations may be complicated 
by historical events. The first feature that requires an explanation is the apparent contradiction between the existence of substantial differentiation between populations of Atherina boyeri and the fact that the most common haplotype is shared between the two rivers and occurs in a large proportion of fish in both cases (12 in 22 fish for Tagus and 12 in 28 fish for Mondego). This finding is consistent with the possibility of the two populations having a relatively recent origin, both having derived from a common genetic pool. This interpretation agrees with the results obtained concerning the historical demography of these fish. The populations of A. boyeri seem to have had a less stable history than that of A. presbyter. Their effective size at the LGM corresponds to a much lower proportion of their current size. Their coalescence times are much smaller than for A. presbyter. Finally, they show a higher growth parameter suggesting that a rapid expansion has taken place after a severe bottleneck.

It is known that at LGM the Portuguese coast was bathed by sub-polar waters (Alveirinho-Dias et al., 1997), and fish of the genus Atherina are not found at very cold waters. It is likely that Atherina presbyter was extinct along the Portuguese shore, but the population may have simply moved south recolonizing the area in the current interglacial. On the contrary, Atherina boyeri populations in rivers and lagoons likely went extinct without being able to move freely as temperatures fell. This would explain the much more recent coalescence times estimated for A. boyeri, which probably recolonized the Portuguese rivers after the end of the last cold period from western Mediterranean refugia. It would also explain the presence of the same haplotype in a large proportion of fish in Tagus and Mondego. In their phylogeographic study, Astolfi et al. (2005) showed that the Atlantic populations of A. boyeri were less diverse than those of the western Mediterranean, despite the two groups being closely related phylogenetically.

Although Atherina boyeri is a fish characteristic of lagoons and rivers, it can tolerate the salinity of fully marine water (Pombo et al., 2005). Thus, it is likely that, although the majority of individuals remain in their natal habitat, a small fraction may disperse through the sea eventually reaching adjacent lagoons or rivers.

The present study highlights a historical dimension in the way the physical differences between marine and riverine habitats may affect organisms when adverse conditions occur: while a marine species may shift its range tracking climatic oscillations and retaining much of their genetic diversity, that possibility is not available to organisms that depend on lagoons and rivers.

\section{Acknowledgements}

This research was supported by a grant from FCT to S.M. Francisco (SFRH/BD/12653/2003). The UIE-ISPA is funded by FCT through the pluri-annual and programmatic funding scheme (FEDER) as research unit UI\&D \#331/94. This study was also funded by the research grant PNAT/1999/BIA/15017. The authors are grateful to Carla Lopes, Lúcia Pombo, Filipe Martinho and Ricardo Leitão for their help in the collection of samples.

\section{Appendix A}

Control region haplotypes, accession numbers, and observed frequency in each location are listed in Table A.1.

\begin{tabular}{|c|c|c|c|}
\hline \multirow[t]{2}{*}{ Haplotype } & \multirow[t]{2}{*}{ Accession number } & \multicolumn{2}{|l|}{ Location } \\
\hline & & Aveiro & Fonte-da-Telha \\
\hline \multicolumn{4}{|c|}{ Atherina presbyter } \\
\hline 1 & DQ336715 & & 1 \\
\hline 2 & DQ336716 & & 1 \\
\hline 3 & DQ336717 & & 1 \\
\hline 4 & DQ336718 & & 1 \\
\hline 5 & DQ336719 & & 1 \\
\hline 6 & DQ336720 & 1 & \\
\hline 7 & DQ336721-DQ336723 & 1 & 2 \\
\hline 8 & DQ336724 & & 1 \\
\hline 9 & DQ336725 & 1 & \\
\hline 10 & DQ336756 & 1 & \\
\hline 11 & DQ336727 & 1 & \\
\hline 12 & DQ336728 & & 1 \\
\hline 13 & DQ336729 & 1 & \\
\hline 14 & DQ336730-DQ336736 & 6 & 1 \\
\hline 15 & DQ336737 & 1 & \\
\hline 16 & DQ336738-DQ336739 & 1 & 1 \\
\hline 17 & DQ336740 & & 1 \\
\hline 18 & DQ336741 & 1 & \\
\hline 19 & DQ336742 & & 1 \\
\hline 20 & DQ336743 & 1 & \\
\hline 21 & DQ336744 & & 1 \\
\hline 22 & DQ336745 & 1 & \\
\hline 23 & DQ336746 & & 1 \\
\hline 24 & DQ336747 & & 1 \\
\hline 25 & DQ336748 & & 1 \\
\hline 26 & DQ336749 & 1 & \\
\hline 27 & DQ336750 & 1 & \\
\hline 28 & DQ336751 & & 1 \\
\hline 29 & DQ336752 & 1 & \\
\hline 30 & DQ336753-DQ336754 & 1 & 1 \\
\hline 31 & DQ336755 & 1 & \\
\hline 32 & DQ336756 & & 1 \\
\hline 33 & DQ336757 & & 1 \\
\hline 34 & DQ336758-DQ336762 & 1 & 4 \\
\hline 35 & DQ336763 & 1 & \\
\hline \multirow[t]{2}{*}{36} & DQ336764 & & 1 \\
\hline & & Mondego & Tagus \\
\hline \multicolumn{4}{|c|}{ Atherina boyeri } \\
\hline 37 & DQ336765-DQ336767 & 1 & 2 \\
\hline 38 & DQ336768-DQ336778 & 10 & 1 \\
\hline 39 & DQ336779 & 1 & \\
\hline 40 & DQ336780 & 1 & \\
\hline 41 & DQ336781-DQ336782 & 1 & 1 \\
\hline 42 & DQ336783 & 1 & \\
\hline 43 & DC336784 & & 1 \\
\hline 44 & DQ336785 & & 1 \\
\hline 45 & DQ336786-DQ336809 & 12 & 12 \\
\hline 46 & DQ336810-DQ336811 & & 2 \\
\hline 47 & DQ336812 & & 1 \\
\hline 48 & DQ336813 & & 1 \\
\hline 49 & DQ336814 & 1 & \\
\hline
\end{tabular}




\section{References}

Alveirinho-Dias, J., Rodrigues, A., Magalhães, F., 1997. Evolução da linha de costa, em Portugal, desde o último máximo glaciário até à actualidade: Síntese dos conhecimentos. Estudos do Quaternário 1, 53-66.

Astolfi, L., Dupanlouop, I., Rossi, R., Bisol, P.M., Faure, E., Congiu, L., 2005. Mitochondrial variability of sand smelt (Atherina boyeri, Risso, 1810) populations from North Mediterranean coastal lagoons. Marine Ecology Progress Series 297, 233-243.

Bamber, R.N., Henderson, P.A., 1988. Pre-adaptive plasticity in atherinids and the estuarine seat of teleost evolution. Journal of Fish Biology 33, $17-23$.

Bamber, R.N., Henderson, P.A., Turnpenny, A.W.H., 1985. The early life history of the sand smelt (Atherina presbyter). Journal of the Marine Biological Association of the United Kingdom 65, 697-706.

Barbour, C.D., 1973. A biogeographical history of Chirostoma (Pisces: Atherinidae): a species flock from the Mexican Plateau. Copeia 1973, 533-556.

Beheregaray, L.B., Sunnucks, P., Briscoe, D.A., 2002. A rapid fish radiation associated with the last sea-level changes in southern Brazil: the silverside Odontesthes perugiae complex. Proceedings of the Royal Society of London B 269, 65-73.

Beheregaray, L.B., Sunnucks, P., 2001. Fine-scale genetic structure, estuarine colonization and incipient speciation in the marine silverside fish Odontesthes argentinensis. Molecular Ecology 10, 2849-2866.

Castelloe, J.T., Templeton, A.R., 1994. Root probabilities for intra-specific gene trees under neutral coalescent theory. Molecular Phylogenetics and Evolution 3, 102-113.

Clement, M., Posada, D., Crandall, K.A., 2000. TCS: a computer program to estimate gene genealogies. Molecular Ecology 9, 1657-1659.

Congiu, L., Rossi, R., Colombo, G., 2002. Population analysis of the sand smelt Atherina boyeri (Teleostei Atherinidae), from Italian coastal lagoons by random amplified polymorphic DNA. Marine Ecology Progress Series 229, 279-289.

Domingues, V.S., Bucciarelli, G., Almada, V.C., Bernardi, G., 2005. Historical colonization and demography of the Mediterranean damselfish, Chromis chromis. Molecular Ecology 13. doi:10.1111/j.1365-294X.2005.02723.

Donaldson, K.A., Wilson, R.R., 1999. Amphi-Panamaic geminates of snook (Percoidei: Centropomidae) provide a calibration of the divergence rates in the mitochondrial DNA control region of fishes. Molecular Phylogenetics and Evolution 13, 208-213.

Excoffier, L., Smouse, P.E., Quattro, J.M., 1992. Analysis of molecular variance inferred from metric distances among DNA haplotypes: application to human mitochondrial DNA restriction data. Genetics 131, 479-491.

Excoffier, L., Laval, G., Schneider, S., 2005. Arlequin ver. 3.0: An integrated software package for population genetics data analysis. Evolutionary Bioinformatics Online 1, 47-50.

Fu, Y.X., 1997. Statistical tests of neutrality of mutations against population growth, hitchhiking and background selection. Genetics 147, 915-925.

Hewitt, G.M., 2001. Spetiation, hybrid zones and phylogeography - or seeing genes in space and time. Molecular Ecology 10, 537-549.
Kuhner, M.K., Yamato, J., Beerli, P., Smith, L.P., Rynes, E., Walkup, E., Li, C., Sloan, J., Colacurcio, P., Felsenstein, J., 2005. Lamarc version 2.0. University of Washington. http://evolution.gs.washington.edu/lamarc.html.

Leonardos, I., Sinis, A., 2000. Age, growth and mortality of Atherina boyeri Risso 1810 (Pisces: Atherinidae) in the Mesolongi and Etolikon lagoons (W. Greece). Fisheries Research 45, 81-98.

Leonardos, I.D., 2001. Ecology and exploitation pattern of a landlocked population of sand smelt, Atherina boyeri (Risso 1810), in Trichonis Lake (western Greece). Journal of Applied Ichthyology 17, 262-266.

Lorenzo, J.M., Pajuelo, J.G., 1999. Age and growth of the sand smelt Atherina (Hepsetia) presbyter Cuvier 1829 in the Canary Islands (Central-east Atlantic). Fisheries Research 41, 177-182.

Munday, P.L., Jones, G.P., 1998. The ecological implications of small body size among coral reef fishes. Oceanography and Marine Biology Annual Review 36, 373-441.

Ostellari, L., Bargelloni, L., Penzo, E., Patarnello, P., Patarnello, T., 1996. Optimization of single-strand conformation polymorphism and sequence analysis of the mitochondrial control region in Pagellus bogaraveo (Sparidae, Teleostei): rationalized tools in fish population biology. Animal Genetics 27, 423-427.

Pombo, L., Elliot, M., Rebelo, J.E., 2005. Ecology, age and growth of Atherina boyeri and Atherina presbyter in the Ria de Aveiro, Portugal. Cymbium 29, $47-51$.

Quignard, J.P., Pras, A., 1986. Atherinidae. In: Whitehead, P., Bauchot, M.L., Hureau, J.C., Nielsen, J., Tortonese, E. (Eds.), Fishes of the North-eastern Atlantic and the Mediterranean. UNESCO, Paris, pp. 1207-1210.

Ramos-Onsins, S.E., Rozas, J., 2002. Statistical properties of new neutrality tests against population growth. Molecular Biology and Evolution 19, 2092-2100.

Raymond, M., Rousset, F., 1995. An exact test for population differentiation. Evolution 49, 1280-1283.

Russel, F.S., 1976. The Eggs and Planktonic Stages of British Marine Fishes. Academic Press, London, 524 pp.

Sambrook, J., Fritscher, E.F., Maniatis, T., 1989. In: second ed (Ed.), Molecular Cloning: A Laboratory Manual. Cold Spring Harbor Laboratory Press, New York.

Schneider, S., Excoffier, L., 1999. Estimation of past demographic parameters from the distribution of pairwise differences when the mutation rates vary among sites: application to human mitochondrial DNA. Genetics 152, 1079-1089.

Swofford, D.L., 2000. PAUP* Phylogenetic Analysis Using Parsimony (*And Other Methods), Version 4. Sinauer Associates Inc., Sunderland, MA, USA.

Templeton, A.R., Crandall, K.A., Sing, C.F., 1992. A cladistic analysis of phenotypic associations with haplotypes inferred from restriction endonuclease mapping and DNA sequence data. III. Cladogram estimation. Genetics 132, 619-633.

Thompson, J.D., Gibson, T.J., Plewniak, F., Jeanmougin, F., Higgins, D.G., 1997. The Clustal X windows interface: flexible strategies for multiple sequence alignment aided by quality analysis tools. Nucleic Acids Research 25, 4876-4882.

Ward, R.D., Woodwark, M., Skibinski, D.O.F., 1994. A comparison of genetic diversity levels in marine, freshwater and anadromous fishes. Journal of Fish Biology 44, 213-232. 